\title{
Features of Emotional Information Transfer When Translating Specialised Texts (a Case Study of Textbook on Management)
}

\author{
Svetlana CHUSOVLYANOVA \\ Ph.D. (in Social Sciences) \\ Associate Professor \\ Foreign Languages Department \\ Siberian Transport University \\ Novosibirsk, the Russian Federation \\ c10506@yandex.ru
}

\section{Yuliya SEROSHTANOVA}

Undergraduate Student

Foreign Languages Department

Siberian Transport University

Novosibirsk, the Russian Federation

seroshtantovayulia@yandex.ru

\begin{abstract}
The paper considers the peculiarities of transmitting emotional information in the process of translation. The relevance of this work lies in the need to find out the means of expressing emotional information in specialized professional-oriented texts for subsequent adequate and equivalent translation. The purpose of this work is to study ways of transmitting emotional information when translating a special text. The article provides an analysis of the literature on the research topic, as well as an analysis of theoretical approaches to the study of emotional information in the text. General scientific and linguistic methods (analysis, comparison, contextual analysis, structural-semantic and lexical-semantic analysis) were used as research methods. The authors study approaches to translating special texts, analyze the functions of emotional information in the management text from the point of view of translation studies, present a quantitative analysis of ways to express emotional information, as well as techniques for translating emotional information into Russian. As a result, we determined that the texts of this style are characterized by a consistent and logical presentation of information, the presence of terms and abbreviations. From a pragmatic
\end{abstract}


point of view, these texts are characterized by the presence of content components, which is explained by the presence of lexical abbreviations and terms, as well as formal components represented by drawings.

Keywords: emotional information; translation process; specialized text.

\section{Introduction}

Management of organizations in the process of training personnel uses a significant amount of foreign literature: operating manuals and other specialized literature. Currently, English-language literature is widely used in training specialists in many industries. Texts addressed to specialists in English allow the presence of emotionally colored vocabulary, but this phenomenon is much less evident in Russian. There is a problem of perception of emotional vocabulary in special texts by the Russian reader due to cultural features.

The purpose of this work is to study ways of transmitting emotional information when translating a specialized text. To achieve this goal, the following tasks were set and solved: to determine and classify the ways of expression and functions of emotional information in a special text; to determine the methods of transmitting emotional information in a special text.

\section{Literature review}

Scientific texts are specialized in the transmission of cognitive information. A special type of information and their cognitive function is determined by the specifics of professional communication. The function of scientific style texts is to transmit logical information and prove its truth, in the absence of any expression of emotions (in Russian language). Here it is worth considering that, due to cultural characteristics, the proof of the truth of scientific information in different languages is carried out in different ways (Stolze, 2009). For example, in the Russian language culture the author of the scientific text has less freedom, while in the English language tradition, a break from the academic writing style is there largely (Misuno, Bacenko, Vdovichev, Ignatova, 2013). American specialized texts often found a bright, stylistically colored vocabulary and its mechanical transfer into Russian, the translation would be contrary to the requirements of the Russian specialized text (Alekseeva, 2015). Taking into account all the above information, we have formulated the following definition: American specialized text is a special type of written communication related to a certain branch of knowledge, the peculiarity of this type of text is the presence of emotionally colored vocabulary, bright methods of transmitting information used in the American English-speaking space. 
Nelyubin under the special text understands the text relating to a certain area of knowledge and professional industry, which has a terminological nomenclature (Strategic HR inc., 2014). The specialized text must meet the requirements of the scientific and technical style has the characteristics of the scientific and technical genre of the corresponding texts. This implies its standardization and stylistic uniformity (Pfau, Humblé, 2019). The main function of a special text can be considered an explanation, which includes fixing the process of knowledge, describing its results, fixing the ways of applying these results (Klyoster, Shumajlova, 2017).

Nebylitsin defines emotional information as the attitude of the author of a statement to the information transmitted (Nebylicin, 2015). Misuno notes that emotional information expresses information about the feelings expressed by the author. It is transmitted by means of emotionally colored vocabulary and syntactic structures peculiar to each specific functional style and each speech genre of a particular language (Nelyubin, 2003). Alekseeva also claims that emotional (expressive) information contains a message about human emotions. By transmitting emotions, language performs an expressive function (Alekseeva, 2004). In our work, we further adhere to the definition of Alekseeva.

Emotional information is used to convey emotions (feelings) in the process of communication. According to its typological features, this type of information is in many ways the opposite of cognitive information. The leading signs of emotional information are subjectivity, concreteness, and imagery (Alekseeva, 2004).

Ways to express subjectivity are words with modal meaning, non-normative vocabulary, including those related to social variants of the language, colloquialisms, swearing, taboo vocabulary, jargon, professionalisms, high-style vocabulary; territorial variants of vocabulary: dialectisms; diachronic variants: archaisms, historisms, neologisms, emotional-evaluative vocabulary (Sdobnikov, 2018). Concreteness is manifested both in the binding of content to a specific time and in the predominance of vocabulary organized according to word-formation models, in which the seme of abstraction is on the periphery, and in the abundance of semantically full verbs. In the organization of textual unity, emotional information declares itself by a small explication of the means of cohesion; the associative principle of connecting individual sentences into a single whole prevails. Imagery is expressed using phraseology, Proverbs, clichéd metaphors, comparisons, and so on. p., which allow associative generalization of information, figuratively compare it with another, already known to the recipient (Alekseeva, 2004).

Thus, taking into account the above methods of expressing emotional information, we have divided them into two groups: 
- linguistic (modal words, extra-normative vocabulary, colloquialisms, jargon, emotionalevaluative vocabulary, phraseological units, Proverbs, comparisons, etc.);

- extralinguistic: explicit means of cohesion: drawings, diagrams, text division, graphic text selection.

Based on the ways of expressing emotional information, we have identified its main functions, which we will continue to adhere to in the work: forming an image that is understandable to the reader; emphasizing the importance; encouraging action; persuading the reader.

The function of forming an image that is understandable to the reader helps to establish contact with the recipient, to form in his mind a certain image of a particular situation. It is necessary to emphasize the importance in the most significant situational contexts, where the reader needs to focus all his attention. Emotional information, which serves as an incentive to action, forces the reader to take any measures to achieve his further goals. The persuasion function allows you to influence the reader in such a way that the author's opinion about a particular issue becomes close to him.

\section{Methods}

The research material is the text of the textbook Critical touch points of recruitment (Kočote, Smirnova, 2016). The author of the tutorial is a group of specialists from the international company Strategic HR inc., working in the field of human resources and management. The company was founded in 1995 in USA, Ohio, Cincinnati.

In the course of the study, the first 11,231 printed characters without spaces were taken, and linguistic and extralinguistic ways of expressing emotional information were calculated using a continuous sampling method.

Approved general scientific and linguistic methods (analysis, comparison, contextual analysis, structural-semantic and lexical-semantic analysis) were used as research methods. Translation transformation techniques were also used.

\section{Results}

Each of these attributes has different ways and types of expression. In our work, the frequency of such techniques is determined. The data is presented in Table 1.

Table 1. Ways to express emotional information in an American specialised text

$$
\text { Characteristic Way of expressing Type of expression Number }
$$




\begin{tabular}{|c|c|c|c|}
\hline \multirow[t]{5}{*}{ Subjectivity } & $\begin{array}{l}\text { Emotional and evaluative } \\
\text { vocabulary }\end{array}$ & linguistic & 26 \\
\hline & Jargons & linguistic & 10 \\
\hline & Professionalisms & linguistic & 9 \\
\hline & Neologisms & linguistic & 7 \\
\hline & Modal words & linguistic & 2 \\
\hline \multirow[t]{3}{*}{ Specificity } & Drawings & extralinguistic & 11 \\
\hline & Text Format (font) & extralinguistic & 9 \\
\hline & Text division (chapter) & extralinguistic & 31 \\
\hline \multirow[t]{3}{*}{ Imagery } & Phraseologisms & linguistic & 11 \\
\hline & Metaphors & linguistic & 5 \\
\hline & Comparisons & linguistic & 7 \\
\hline
\end{tabular}

128 ways of expressing emotional information were allocated for 11,231 printed characters without spaces.

After analyzing the results shown in the table, we see that emotional-evaluative vocabulary is present in a large number in this text. This is due to the fact that the author needs to express his attitude to the issue being studied in the text, to express subjectivity, which is helped by words with an emotional assessment. Phraseological units allow the author to form a certain image in the reader, thereby establishing a closer contact. The explicitness of the means of cohesion (conditional 
drawings, text division and text formatting) allows the author to attract the reader's attention by highlighting the main information in a graphic way.

As we have established, emotional information performs a certain set of functions, namely: prompting to action; (exclamation marks); convincing the reader; - forming an image that is understandable to the reader; emphasizing the importance of the message. The above-mentioned functions were also present in our special text, and their quantitative analysis is presented below.

Table 2. Quantitative analysis of the functions of emotional information

\begin{tabular}{ll} 
Function & Frequency of use \\
\hline Creating an image that is understandable to the reader & 74 \\
\hline Emphasizing the importance & 51 \\
\hline Motivation for action & 8 \\
\hline Reader's belief & 8
\end{tabular}

Thus, we come to the conclusion that the main function that emotional information performs in the American special text is to form an image that is understandable to the reader. Moreover, extralinguistic ways of expressing emotional information often serve the function of "emphasizing importance", drawing the reader's attention to the most important aspects of the text.

We have previously established that emotional information is expressed in linguistic and extralinguistic ways. Since in a specialized text we are faced with both types of such expressions, it is necessary to understand what translation techniques will help us to maintain the functional and situational content of the context when transmitting emotional information.

Translation techniques are types of operations performed by the translator on the original text in order to obtain the translation text (Strategic HR inc., 2014). Let us consider translation techniques for transmitting emotional information and linguistic ways of expressing it. Summary data are given in Table 3.

Table 3. Translation techniques for linguistic ways of expressing emotional information

\begin{tabular}{lllll}
$\begin{array}{c}\text { Way of } \\
\text { expressing }\end{array}$ & Function & Example & \multicolumn{1}{c}{ Translation } & $\begin{array}{c}\text { Translation } \\
\text { technique }\end{array}$ \\
\hline Emotional and & Creating an image & Creating the perfect & Создание подходящего по & Semantic \\
evaluative & that the reader can & job posting (i.e. & всем параметрам рабочего development \\
& & advertisement) is & объявления (т.е. рекламы)
\end{tabular}


Dictum Factum

\begin{tabular}{|c|c|c|c|c|}
\hline vocabulary & understand & where it all begins. & является отправной точкой. & \\
\hline Modal words & $\begin{array}{l}\text { Creating an image } \\
\text { that the reader can } \\
\text { understand }\end{array}$ & $\begin{array}{l}\text { Unfortunately most } \\
\text { candidates don't really } \\
\text { care what you want - } \\
\text { they want to know } \\
\text { what they will get out } \\
\text { of a job. }\end{array}$ & $\begin{array}{l}\text { К сожалению, } \\
\text { большинство кандидатов } \\
\text { заботятся только о личной } \\
\text { выгоде, а не о том, что } \\
\text { хочет работодатель. }\end{array}$ & $\begin{array}{l}\text { Literal } \\
\text { translation }\end{array}$ \\
\hline Jargons & $\begin{array}{l}\text { Creating an image } \\
\text { that the reader can } \\
\text { understand }\end{array}$ & $\begin{array}{l}\text { WIIFM: What's In It } \\
\text { For Me? }\end{array}$ & $\begin{array}{l}\text { Что меня привлекает в } \\
\text { данной должности? }\end{array}$ & $\begin{array}{l}\text { Semantic } \\
\text { development }\end{array}$ \\
\hline Professionalisms & $\begin{array}{l}\text { Creating an image } \\
\text { that the reader can } \\
\text { understand }\end{array}$ & $\begin{array}{l}\text { This information will } \\
\text { help you determine } \\
\text { your strategy for } \\
\text { where you may find } \\
\text { your ideal candidate, } \\
\text { i.e. online, } \\
\text { newspapers, } \\
\text { outplacement centers, } \\
\text { social media, and how } \\
\text { you will sell the job } \\
\text { to them? }\end{array}$ & $\begin{array}{l}\text { Такая информация поможет } \\
\text { определить стратегию } \\
\text { поиска идеального } \\
\text { кандидата: через интернет, } \\
\text { газеты, центры } \\
\text { трудоустройства или же } \\
\text { социальные сети, и как } \\
\text { убедить его обратиться } \\
\text { именно к вам }\end{array}$ & $\begin{array}{l}\text { Semantic } \\
\text { development }\end{array}$ \\
\hline
\end{tabular}

\begin{tabular}{|c|c|c|c|c|}
\hline Neologisms & $\begin{array}{l}\text { Creating an image } \\
\text { that the reader can } \\
\text { understand }\end{array}$ & $\begin{array}{l}\text { What skills or } \\
\text { qualities are "must } \\
\text { haves", "nice to } \\
\text { haves" and "deal- } \\
\text { breakers"? }\end{array}$ & $\begin{array}{l}\text { Какие навыки и качества } \\
\text { потенциального кандидата } \\
\text { обязательны, желательны } \\
\text { и препятствуют } \\
\text { прохождению дальше? }\end{array}$ & $\begin{array}{l}\text { Semantic } \\
\text { development }\end{array}$ \\
\hline Phraseologisms & $\begin{array}{l}\text { Creating an image } \\
\text { that the reader can } \\
\text { understand }\end{array}$ & $\begin{array}{l}\text { Put yourself in the } \\
\text { candidates' shoes. }\end{array}$ & $\begin{array}{l}\text { Представьте себя на месте } \\
\text { кандидатов. }\end{array}$ & $\begin{array}{l}\text { Full } \\
\text { transformati } \\
\text { on }\end{array}$ \\
\hline Metaphors & $\begin{array}{l}\text { Creating an image } \\
\text { that the reader can } \\
\text { understand }\end{array}$ & $\begin{array}{l}\text { Here's an example of } \\
\text { a poor job posting. }\end{array}$ & $\begin{array}{l}\text { Далее вы ознакомитесь с } \\
\text { объявлением, которое } \\
\text { лучше не повторять. }\end{array}$ & $\begin{array}{l}\text { Semantic } \\
\text { development }\end{array}$ \\
\hline
\end{tabular}


Table 2 clearly shows that when transferring linguistic ways of expressing emotional information, it is necessary to resort to such translation techniques as semantic development, full transformation, and in some cases, literal translation is also possible.

Next, we will consider methods for transmitting extralinguistic ways of expressing emotional information, while specifying the method of expressing information and a function in the text.

Table 4. Methods of transferring extralinguistic ways of expressing emotional information

\begin{tabular}{|c|c|c|c|c|}
\hline $\begin{array}{c}\text { Way of } \\
\text { expressing }\end{array}$ & Function & Example & Translation & $\begin{array}{l}\text { Translation } \\
\text { technique }\end{array}$ \\
\hline Text format & $\begin{array}{l}\text { To emphasize } \\
\text { the importance }\end{array}$ & $\begin{array}{l}\text { You need to find out why } \\
\text { someone WOULD want } \\
\text { to work for you and } \\
\text { develop your messaging } \\
\text { around that - your } \\
\text { Employment Brand. }\end{array}$ & $\begin{array}{l}\text { Необходимо } \\
\text { определить, почему кто- } \\
\text { то захочет работать } \\
\text { именно на вас и } \\
\text { распространить эту } \\
\text { информацию, иными } \\
\text { словами, продвигать } \\
\text { бренд фирмы. }\end{array}$ & $\begin{array}{l}\text { Stylistic } \\
\text { neutralization }\end{array}$ \\
\hline Text format & Convincing & $\begin{array}{l}\text { Does your company have } \\
\text { a defined employment } \\
\text { brand? It should! }\end{array}$ & $\begin{array}{l}\text { Ваша компания имеет } \\
\text { свой выраженный } \\
\text { бренд? Он обязательно } \\
\text { должен присутствовать. }\end{array}$ & $\begin{array}{l}\text { Full } \\
\text { transformation }\end{array}$ \\
\hline Text format & Convincing & $\begin{array}{l}\text { Yes, this is an actual job } \\
\text { posting copied from one } \\
\text { of the major job boards. } \\
\text { BORING! }\end{array}$ & $\begin{array}{l}\text { Да, это объявление } \\
\text { является реальным и } \\
\text { взято с одной из } \\
\text { основных бирж труда. } \\
\text { Не вызывает интереса, } \\
\text { не так ли? }\end{array}$ & $\begin{array}{l}\text { Full } \\
\text { transformation }\end{array}$ \\
\hline Text format & A call to action & Make it easy! & $\begin{array}{l}\text { Давайте упростим этот } \\
\text { процесс. }\end{array}$ & $\begin{array}{l}\text { Full } \\
\text { transformation }\end{array}$ \\
\hline
\end{tabular}

Table 3 shows that the techniques for transferring emotional information mainly include neutralization, semantic development, full transformation, as well as techniques such as literal translation and taking the word in quotation marks.

\section{Discussion}


We have previously established that emotional information is expressed in linguistic and extralinguistic ways. Since in a special text we are faced with both types of such expressions, it is necessary to understand what translation techniques will help us to preserve the functional and situational content of the context when transferring emotional information. The presence of extralinguistic factors in the translation of a text largely determines the disclosure of the meaning of certain words. Since we are currently talking about transferring emotional information in a special text, these factors are of great importance. Translation of some constructions is possible only if the translator has extralinguistic knowledge of a particular industry.

\section{Conclusion}

As a result of the research, we determined that the texts of this style are characterized by a consistent and logical presentation of information, the presence of terms and abbreviations. From a pragmatic point of view, these texts are characterized by the presence of content components, which is explained by the presence of lexical abbreviations, abbreviations and terms, as well as formal components represented by drawings.

We determined that when translating a special text, it is necessary to take into account that it is characterized by the use of special professional knowledge, which is realized by using abstract vocabulary, uniformity of vocabulary and the presence of passive, vaguely personal and impersonal constructions at three levels of language analysis-lexical, syntactic, and pragmatic.

Based on the work done, we have come to the conclusion that the following translation recommendations should be followed when transmitting emotional information from a special American text:

1. The translation of emotionally valued vocabulary, metaphors, jargon, professionalism, and various comparisons should be carried out using such translation techniques as semantic development and full transformation; in some cases, it is possible to take the word in quotation marks.

2. The translation of modal words be done through literal translation.

3. Conditional drawings and symbols of the original text must be retained in the text of the translation.

4. The transfer of various graphic font selections in the source text should be carried out in the translation text according to the requirements for the Russian specialized text. 
5. The text of translation should be divided according to the requirements of the Russian special text.

In conclusion, it should be noted that the presence of extralinguistic factors in the translation of the text is largely decisive in revealing the meaning of certain words. Since we are talking about the transmission of emotional information in a special text, extralinguistic factors are of great importance. Translation of some constructions is possible only if the translator has extra-linguistic knowledge of a particular industry.

\section{References}

Alekseeva, I.S. (2004). Vvedenie v perevodovedenie. Izdatel'skij centr: «Akademiya». (in Russian)

Alekseeva, T.D. (2015). Osobennosti special'nogo perevoda v neyazykovom vuze. Sovremennye tendencii razvitiya nauki i tekhnologij, 1-3, 108-111. (in Russian)

Klyoster, A.M., Shumajlova, M.S. (2017). Opisanie modeli special'nogo teksta. Gramota, 7(73), 2, 107-109.

Kočote, I., Smirnova, T. (2016). Aspects of Military-related Text Translation from English into Latvian. Procedia - Social and Behavioral Sciences, 231, 107-113. Retrieved from: https://doi.org/10.1016/j.sbspro.2016.09.078 (Accessed on October 20, 2019)

Misuno, E.A., Bacenko, I.V., Vdovichev, A.V., Ignatova, S.A. (2013). Pis'mennyj perevod special'nyh tekstov: ucheb. posobie. Moscow: FLINTA. (in Russian)

Nebylicin, A.A. (2015). Emocional'naya informaciya i eyo sostavlyayushchie: ekspressivnaya intensivnost'. Filologicheskie nauki. Voprosy teorii i praktiki, 10, 135-137.

Nelyubin, L.L. (2003). Tolkovyj perevodcheskij slovar'. Moscow: Flinta: Nauka. (in Russian)

Pfau, M., Humblé, P. (2019). Translation Analysis of Academic Texts in the Human Sciences: A Case Study. Cadernos de Tradução, 39(2), 146-165. Retrieved from: https://doi.org/10.5007/2175-7968.2019v39n2p146 (Accessed on November 20, 2019)

Sdobnikov, V.V. (2018). Translation vs localization: what's the difference? Journal of Siberian Federal University. Humanities \& Social Sciences, 11(9), 1487-1498. Retrieved from: https://doi.org/doi:10.17516/1997-1370-0317 (Accessed on November 19, 2019).

Stolze, R. (2009). Dealing with cultural elements in technical texts for translation. The Journal of Specialised Translation, 11, 124-142. 
Dictum Factum

Strategic HR inc. (2014). Critical touch points of recruitment. Retrieved from:

https://bookboon.com/en/critical-touch-points-of-recruitment-ebook (Accessed on November 18, 2019). 